\title{
Methodological Reflections on the Study of Chinese Christianities
}

\author{
Joseph Tse-Hei Lee and Christie Chui-Shan Chow
}

To stage a meaningful dialogue between China area studies and Christianity worldwide, this chapter draws on the changing landscape of Chinese Christianities to reframe certain parameters and norms in the study of global Christian movements. By focusing on the interplay between global religious forces and local conditions, this chapter argues that the Chinese concern about global-local church ties is largely defined by the very question of churchstate relations. The voices and narratives of Chinese Christians throw light on their own understanding of the global Christian body and on their ongoing struggles to define an authentic religious identity in a state-centric society.

The existing debate about what constitutes Christianity in China is fraught with two misconceptions. First, there has been a tendency to define an indigenous church against Euro-American missionary Christianity. This nationalistic narrative of Christianity in China was derived from the post-1949 ideological environment, where separating the ties between Chinese and global churches has been a political agenda of the Communist state. Second, Christian groupings in China are diverse and fragmentary. Analytical terms like 'Chinese Christianity' and 'popular Christianity' are too simplistic and ignore many transnational, intra-/inter-church boundaries arising from doctrinal, liturgical and political disagreements. Today most of the missionary-founded churches such as the Anglicans, Baptists, Presbyterians and Seventh-day Adventists as well as indigenous movements like Watchman Nee's Little Flock and the True Jesus Church, and recently, some zealous Christian groups like The Church of Almighty God, have not only survived persecution but also become an integral part of global Christianity, exporting their own doctrines and faith practices worldwide. To locate China's rich and diverse Christian experience within the broader landscape of Christianity, this chapter proposes an alternative way to rewriting the state-centered church history. It shows that the Chinese Protestant expressions of Christianity took root in resistance to 
missionary efforts during the nineteenth and twentieth centuries that failed to win the hearts and minds of the people, and to decades of concentrated persecution of churches and believers under the Communist rule. However, the question of state domination continues to shape scholarly understanding of Christian experience in China. The production of knowledge about Chinese churches is affected by the state's control over access to the official archives. It is not just the Christian communities who fear the mighty state; the state fears them, knowing the importance of historical memory in shaping collective consciousness of the churches. To explain the creative tension of these complex church-state encounters, this chapter highlights a number of methodological issues arising from archival research and fieldwork in the study of Protestant Christianity in China. Integrating archival research with multi-site fieldwork may be the best way to circumvent official censorship and move beyond the state-centered historical narrative. This interdisciplinary approach places the historical process of Chinese-Christian interactions at the heart of discussion.

Beginning with an overview of the latest research on Christianity in China, this chapter reviews different types of archival materials and explores the problems of using these primary sources such as how reliable they are, how they shed light on the historical reality of the churches and the ideological climate during which the sources were produced, and how they permit the exploration of new themes not yet covered in previous research. It is followed by a discussion of the comparative advantages and disadvantages of conducting fieldwork among Chinese Christian communities. In particular, it addresses the challenge of interacting with different groups of informants, the varieties of ethnographic data collected, and the scholarly insights of these data. It concludes with an analysis of new possibilities for further research into the Christian experience in today's China.

The first Chinese encounter with Christianity dates back to the Tang dynasty (A.D. 618-907), a period of cosmopolitan openness when foreign religions such as Buddhism, Syriac Christianity, Manichaeism and Zoroastrianism were permitted in China. Evidence from the classical Chinese manuscripts has shown that under the imperial support, the Syriac-speaking Church of the East took the initiative to Christianize the Daoist teaching of Way (dao) and turned it into the idea of the Trinity. They also appropriated the Buddhist teaching on human sufferings and presented an alternative interpretation by stressing the 
deception of Satan, the fall of human beings and, at the same time, the suffering and salvation of the Messiah for the world. The same pattern of cross-cultural interaction can be seen in the Ming and Qing dynasties (A.D. 1368-1911) when European missionaries arrived. Because of the state's persecution during the eighteenth century, the Catholic communities went underground, escaped the direct control of European Catholic missionaries, and developed into a localized network of family cells in coastal and inland provinces (Lee and Laamann 2019). Thus, without a strict surveillance of missionaries, Chinese Catholics had much autonomy to integrate popular religious traditions into their faith practices. This popular and unconscious form of syncretism still characterizes many Catholic communities in China today. What the followers of the Church of the East in the Tang dynasty and of Catholicism in the Ming and Qing periods found in Christianity was the fulfilment of the Confucian ethics and the Buddhist and Daoist ideals. Ordinary converts subscribed to the idea of universal salvation and employed sacred Christian symbols such as crucifixes, icons and Bibles to struggle against evil forces. When the first Protestant missionary Robert Morrison (1782-1834) set foot on Chinese soil in 1807, he built on the previous successes of the Syriac-speaking Church of the East and European Catholic missionaries. He could never have imagined that Christianity would transform itself from a mistrusted and, at times, persecuted 'foreign' religion into a fast-growing and fully indigenized spiritual movement in the twentyfirst century.

Today Catholics and Protestants combined make up between 4 and 6 percent of China's total population of 1.4 billion. This figure represents a significant increase since the Communist Revolution of 1949, when Christians accounted for one percent of the national population, with only three million Catholics and one million Protestants (Bays 2003; Lee 2007; Madsen 2003). The long history of China's encounter with Christianity problematizes what Philip Jenkins describes a "shift of the center of Christianity" from Europe and North America to Asia, Africa and Latin America (Jenkins 2002). In the sixth and seventh centuries, there were more Christian churches in what is now perceived as the 'South' (i.e., China, Inner Asia, Western Asia and Northern Africa) than in the 'North' (i.e., Europe). But the demographic changes in today's Christian population do not necessarily lead to the shift of Christian influences from global North to global South. According to Robert Wuthnow (2010), American churches have utilized the force of globalization to play a significant role in evangelistic and leadership training programs abroad. This explains why contemporary Chinese churches are keen to reconnect with the American counterparts in order to access external theological resources for faith consolidation and funds for program development. 
There has been a heightened awareness among scholars of the need to reconstruct the lived experience of foreign missionaries and native believers, partly because of the sheer size and diversity of the country, and partly because of the long history of Chinese-Christian encounters. Two interpretative angles have shaped their scholarship (Chow forthcoming). The first is to analyze the indigenization of Christianity in the light of Western modernity. This analysis departs from the conventional focus on Western missionary enterprises to the role of conscientious missionaries in indigenizing the gospel and that of native converts as active initiators of faith and practices (Ling 1999; Lutz 2008). Rather than being subordinate recipients, the Chinese proved to be competent church administrators and learned theologians from the beginning, making the gospel more relevant to fellow countrymen, and in doing so, surpassing the Western missionaries (Bays and Widmer 2009; Wang 2007; Wu 2005; Yang 2014). Some Chinese church leaders went so far as to separate themselves from their missionary supervisors and to adapt the theologies and liturgies of Western Christianity into local culture (Bays 1996: 265-366; Constable 1994; Lian 2010).

The second is a China-centered approach that juxtaposes foreign missionary enterprises with home-grown Protestant independent congregations, thereby highlighting the Chinese reception of the gospel, and their unique contributions to the Church (Austin 2007; Clark 2011; Harrison 2013; Sweeten 2001). The biographical studies of home-grown revivalists such as Dora Yu (Yu Cidu 18731931), John Song (Song Shangjie 1901-44), Watchman Nee (Ni Tosheng 1903-72) and Wang Mingdao (1900-91) illustrate this trend. These leaders were once affiliated with the denominational churches, but they broke away from the mission institutions and reinvented themselves as faith-based evangelists. Some eventually created independent congregations like Watchman Nee's Little Flock and Wang Mingdao's Beijing Tabernacle. Dora Yu and John Song were praised for their revivalist teachings and assumed greater spiritual authority than missionaries (Harvey 2002; Roberts 2005; Wu 2002). The importance of native agency in localizing the gospel stands out as the signature focus of this trend (Bays 1996: 309).

However, some limitations can be discerned from these interpretative perspectives. First, there has been a tendency towards the teleological assumption that Christianity first came to China as a foreign religion and only gradually transformed itself into a truly Chinese religion, after separating itself from a Euro-American denominational matrix. A complete discontinuity between missionary Christianity and Chinese Christianity is thus assumed to be inevitable. Second, Chinese Christian groupings turn out to be more diverse than one can imagine, and analytical categories such as 'independent Christianity', 
'indigenous church' and 'popular Christianity' are all-encompassing frameworks that simplify Chinese churches into a homogeneous entity, ignoring numerous intra-church boundaries arising from differences in doctrinal teachings, liturgical practices and socio-political ethics. Third, these trends overlook the living reality of denominationalism within the Chinese Church. Denominationalism has been and is an integral part of Christianity in China, even though Watchman Nee's Little Flock and the True Jesus Church still manifest the respective contours of global Brethren and Pentecostal movements (Inouye 2019; Woodbridge 2019). R.G. Tiedemann has commented on the failure of indigenous churches - the True Jesus Church, the Jesus Family and the Little Flock - to transcend their differences and form a Protestant coalition in response to the rise of (anti-missionary) Chinese nationalism in the 1920 and 1930s. As Tiedemann (2012: 8) asserts:

[W] hen foreign missionary operations ended in China in the middle of the twentieth century, the Protestant movement was far more divided than it had been at the beginning of that century. Indeed, in spite of the best efforts of the authorities in the People's Republic of China to create one unified post-denominational faith, deep divisions persist to this day within indigenous Protestant Christianity.

His remark captures lucidly the paradox of Chinese Protestantism. Along the same reasoning, Christie Chui-Shan Chow states that "the more independent the Chinese Church becomes, the more unlikely that they identify with the secular authorities, transcend their respective group differences, and contribute to the Communist state's discourse of a post-denominational faith" (Chow 2015: 7-8). In the Communist official rhetoric of today, the Chinese Church is characterized as a post-denominational entity loyal to the state, a discourse promoted by the late Chinese bishop of the Three-Self Patriotic Movement, K.H. Ting (1915-2012) (Wickeri 2007). This ideological construct has discouraged scholars from taking seriously the resilience of denominationalism among Chinese Protestants (Wickeri 2015).

An emphasis on the Euro-American denominational features and ecumenical ties of Chinese Christians does not mean that contemporary scholars endorse a reorientation of the Chinese Church to the old mission-led religion. Daniel H. Bays highlights the central role that Chinese Christians played in constructing "a vibrant and firmly grounded Christian community", something which foreign missionaries did not fully achieve during their time in China (Bays 2013: 14). In placing the emphasis on indigeneity, we should not dismiss foreign Christianity as an obsolete phenomenon without any influence. 
Whatever global ideas, institutions and practices the Chinese acquired from the missionaries, they contextualized these and made them their own. Whenever circumstances permitted, they appropriated the foreign influence at hand. In this light, the interplay between global religious currents and local conditions should be the focus of discussion, and the 'Chinese-ness' of Christianity was concerned with the freedom to actualize the gospel and to engage with the surrounding environment, local politics, and overseas mission institutions.

The coexistence of global currents and local vitality resonates with the focus on the unity of Christians across temporal and spatial boundaries in the study of Christianity worldwide. This conceptualization challenges the teleological view that Christianity came to China as a foreign religion and transformed itself into a purely local belief system. As Ryan Dunch (2014) points out, this linear framework is derived from the ideological environment of the early twentieth century, where separating Chinese from global churches was part of the call for the indigenization of the gospel, and this became a key component of the Communist anti-religious policy after 1949. This leads to a scholarly investigation of when Christianity became wholly indigenous and by what criteria that can be assessed. Instead of dichotomizing the global and local ties of Christianity, it is important to acknowledge a symbiotic relationship between localizing Christian faith practices and maintaining fellowship with church communities outside China. The next section historicizes Western missionaries and Chinese Christians as effective forces in maintaining the global-local religious ties and state-society balance.

\section{3 The Study of Christianity in China}

Christians in modern China faced a world that was destabilizing on multiple fronts. Globally, the First World War led to international entanglements facilitated by modern developments in transportation, communication and military technology. Internally, the twentieth century saw the collapse of the Qing dynasty, the establishment of a weak Republican state, the outbreak of the Sino-Japanese War and the Communist Revolution. Not only were the governing institutions plagued by severe violence, but the traditional foundations of Chinese morality, including popular religions and Confucianism, were attacked by the state makers. The dire conditions left a tremendous void in Chinese society (Lee 2018: 1-14). Christianity flourished in areas suffering profound dislocations amid regime change and warfare. This is true for South China's Chaoshan, a region notorious for its long tradition of collective 
violence. The Christian century of South China (186os-present) was characterized by a reciprocal movement involving foreign missionaries and native agents. Local Christians were responsible for spreading the faith through transnational migration routes and kinship ties. Before the rise of nationalism, a Chinese Christian religious sphere was largely defined by linguistic and social networks. These networks were outside the state control and provided additional resources that empowered the church in times of crisis. In areas with little government control, Christianity became a new potent element across China. In an autonomous managerial public sphere, the Chinese Christians assumed the role of a quasi-state, channelling aid from afar and rehabilitating severely affected localities during emergencies (Lee 2014). These faith-based initiatives not only laid the basis for a cohesive and legitimate grassroots authority beneath a fragmented state structure, but also offered valuable spiritual, material and organizational resources to people seeking to make sense of a dangerous world from the late Qing to the 1950s.

The 1950s saw a new era of mission-church relations. After the outbreak of the Korean War on June 25, 1950, the Communist state forced China's Protestant communities to sever their ties with global churches, placed the diverse Protestant denominations under the control of a Leninist mass organization, and purged any church leaders critical of the state-controlled Three-Self Patriotic Movement, a mass organization designed to legitimatize the state's intervention into Chinese church affairs. The Maoist decades of hostile persecution of churches and believers raised important questions about faith and politics in a state-centric society. When the state reasserted its influence in the religious sphere, Christians either participated in the state's quest for legitimacy or resisted the forces of ideological conformity that secular authorities imposed on them (Lee 2017).

What happened to ordinary Christians who were not jailed and persecuted during the darkest moment of the Maoist era (1949-1976)? Christie Chui-Shan Chow (forthcoming) has charted the revival of Adventist Christians in East China's Wenzhou. She observed that rural Adventists developed a localized network of clandestine cells to continue religious activities during the 196os, and they resurfaced as a fully indigenized spiritual movement in the $1980 \mathrm{os}$. These Wenzhou Adventists believed not only that they were called out of this world to follow Jesus Christ and serve humankind, but also that they coexist with any political regime. Several thousand kilometres away, house churches in South China's Chaoshan relied on the Overseas Chinese Christian networks for support and protection. Remittances sent by missionaries, friends and relatives from Hong Kong and Southeast Asia greatly benefited the local Christians (Chow and Lee 2016: 579-599). 
Against this backdrop, the problem of state domination continues to shape our understanding of Christian experience in China. State censorship makes it difficult for people to conduct genuine research on Chinese church history. The construction of scholarly knowledge about Chinese churches is affected by the state's arrangements for and restrictions on access to the archives. The state recognizes the influence of historical memory in shaping collective consciousness of the churches. Accordingly, draconian control of historical knowledge and memory is accompanied by strict supervision of the officially confiscated church archives for research. No historiography exists in a political vacuum. In Maoist China, the reinstatement of a state-sanctioned, triumphalist narrative of the Communist victory against foreign imperialism constrained independent historical investigation. At that time, archives were off limits to church historians, and church documents confiscated or destroyed. Chinese universities and research institutes were instructed to uphold the official Marxist ideological paradigm, and school textbooks outlined official perspectives on the past. These obstacles present a number of methodological issues about archival research and fieldwork in the study of Christianity in China today.

\section{$4 \quad$ Archival Research in China}

What information do we find in the archives about Christianity in China? As John D.Y. Peel (1996) has argued, the great bulk of the Christian missionary archives consists of first-hand accounts of missionary activities and impressions of native evangelistic agents. Of these records, there are countless reports of evangelization: preaching in markets and villages, religious discussions with people from all walks of life including faith seekers, visitors, farmers, merchants, artisans, and traditional religious specialists, all at different levels of formality and informality. As Christian congregations began to take shape on native soil, there are many accounts of religious activities and interactions. These missionary archives document the social and religious life of Christian communities. There is much information about the persecution of converts by non-Christians. Apart from the Sunday services, sermons and hymns, the missionary reports contain much data on the material side of running a mission station: the acquisition of landed property for building churches, missionary residences, schools and hospitals, the erection, maintenance and repair of churches, problems in getting supplies, hiring workers and distributing resources. Interaction with native workers is another interesting issue in the reports. Finally, there are rich ethnographic data and historical photographs about the social environment in which the foreign missions 
operated. Most of what missionaries talked about local society and culture is supplementary to reports of their evangelistic works, and conveys to readers a vivid impression of rural society in specific contexts: the dynamics of popular religious activities, the frequent outbreaks of resource conflicts, the manifestation of intra/inter-village violence, and the impacts of Christianity on local politics.

In addition to missionary archives, which are usually located outside China, there are also archival resources on Christianity in China. One example of such valuable resources are the Chinese state archives. The archival system of the Maoist state was a powerful instrument of control used by the officials in all major political purges. After 1949, the Maoist government implemented the aggressive Three-Self Patriotic Movement to co-opt all Protestants and take over their churches. The authorities confiscated and transferred most of the church records to all the municipal departments of united front, and the purpose was to enable Communist officials in charge of religious affairs to better understand the profile of native church leaders and persecute them. Ironically, this official decision saved the church materials from being destroyed by the Red Guards during the Cultural Revolution (1966-1976). Once China implemented the open-door policy of economic development in the 1980s, many provincial and municipal authorities transferred these confiscated church records to the state archives, which then declassified the materials for the public in the late 199os.

Much has been written about the challenge of conducting archival research in China (Dubois and Kiely 2020; Kraus 2016; Ye and Esherick 1996; Wagner 1998, 2002). How should church historians get access to an official archive in China? Getting a letter of introduction (jieshao xin) from a Chinese academic institution or an affiliated work unit (danwei) is the first step. The letter simply mentions the name of a researcher and the length of one's affiliation with the local work unit. International scholars and research students should work with Chinese universities that have exchange agreements with their home institutions. It is a formality to obtain this letter before applying for permission to do research in any national, provincial and municipal archives.

Upon receiving the official approval, navigating the catalogues is the second challenge. The Chinese archival catalogues broadly divide the collections of historical materials (lishi ziliao) into the pre- and post-1949 era. Any materials that were produced before the Communist Revolution of 1949, known as the period of pre-Liberation, are usually open for research. Yet, archival sources after 1949 could be problematic because the documents reflect badly on the political, social and economic failures of the Maoist regime, and the intense persecutions of Christian communities. 
Accessibility to post-1949 materials impacts the ability to construe comprehensive appreciation of the twentieth-century Chinese Christian experience. During the 1990s and 2000s, a wider accessibility to source materials deepened research on the Chinese churches. At that time, it was easier for foreigners and Chinese to access archival sources on religious affairs. When the ideological climate once more became restrictive, these archives were close to the outside world. Before the Beijing Olympics in 2008, Joseph Tse-Hei Lee visited the Beijing Municipal Archives and found many official reports on the persecution of Wang Mingdao during the mid-195os. When he revisited the same institution in 2012, the staff had removed any references to these reports and the catalogues were filled with empty white space.

On many occasions, archival officials could remove a scholar's access to declassified materials based on ambiguous reasons. One should pay attention to the written archival regulations in order to defend one's right to research. As China embraced advanced strategies of online and offline control, a researcher should be aware of the visible and invisible surveillance systems. In the past, most of the user-friendly archival staff did not want to be burdened with too many photocopying requests, and they often allowed a researcher to photocopy, scan and take photographs of the documents. When the Chinese state tightened ideological control at the higher level, a researcher had to take time to cultivate friendship and earn trust from the staff. In 2013, the senior officials in the Wenzhou Municipal Archives found Christie Chui-Shan Chow consulting the reports on local religious affairs through a surveillance camera, and immediately told the staff to suspend her access. Having spent a few weeks at the archives, Chow gained much respect and trust from the staff. The sympathetic staff eventually allowed Chow to read and copy some of the reports by hand, as long as she did not photograph materials.

Nevertheless, one should never feel discouraged by not getting access to the archival folders on religious affairs. Because the Chinese Communist state penetrated all aspects of public life, many provincial and municipal administrative units were involved in the mass campaigns against foreign missionaries and native churches. These units included the Communist Youth League and the respective bureaus of united front, foreign affairs, healthcare, education and commerce. The archives of these units contain information related to former missionary enterprises and churches in the spheres of medical care, education, commerce and foreign affairs. When these bureaus took over the missionary-run institutions in the 1950s, the first step was to confiscate the archives of local Christian hospitals, schools, universities and welfare agencies. This enabled the officials to gather intelligences and organize anti-Christian rallies against the existing church leadership. The officials later transferred the 
materials to the provincial and municipal archives, and historians have come across many of these former church archives in the provinces of Guangdong, Guangxi, Fujian, Zhejiang, Shandong, Sichuan and Yunnan. Though framed in Marxist, anti-religious tone, these official reports have much data about church-state tensions, and profiles of anti-Communist church leaders. When comparing such reports with ethnographic data about clandestine church activities, one often finds the defiant church staff to lead the house church movements during the 1960s and 1970s.

During his research, Joseph Tse-Hei Lee discovered extensive collections of the American Baptist, Scottish Presbyterian and French Catholic church documents in several municipal and district archives in Guangdong Province during the 199os and 200os. These church documents contain many volumes of the minutes of the Shantou Presbyterian Synod of Chaozhou and Huizhou, Baptist and Presbyterian churches' account books, congregational rolls, correspondence between city and rural churches, conversion testimonies, and records of intra- and inter-church disputes. Some of the declassified Cultural Revolution-era folders include a "secret" (jimi) public security report on Watchman Nee's Little Flock Movement, and the report was circulated across different bureaucratic networks of provincial officials in charge of religious affairs (Lee 2005). Together with the foreign missionary archives, these documents allow scholars to reconstruct the grassroots history of Chinese Christian communities, focusing on the issues of conversion, church governance and mission-church relations, the institutionalization of the training program and mission schools, as well as the formation of Christian lineages and their growing regional and transnational networks.

Moreover, these documents reveal that both foreign missionaries and Chinese workers had put in place a coherent system of church hierarchy before 1949. This institutional trend can be seen in the increasing use of written records, formulaic surveys, and statistical records, the correspondence between different levels of the church hierarchy, the professionalization of native church ministers, and the active involvement of the laity in church governance. The documents enable researchers to map the organizational mechanisms and community resources that foreign missionaries and native church leaders deployed to evangelize the local society. Because the church was staffed by Chinese, their social networks and native knowledge helped to make the system work, shaping the religious hierarchy and allowing it to influence the widely scattered congregations. The best way to get things done was to go directly to the most qualified persons on the ground. Many documents reveal who these persons were and who were better equipped to deal with certain practical problems than the missionaries, to advance the evangelistic 
agenda, and to undertake specific pastoral and mundane tasks. As the church hierarchy was linked through social networks among members of the clergy and laity, the complicated relationship between documentations and actions contains rich data about native knowledge and personal ties. The variety of church practices in different localities, the localization of Anglo-American church management methods, and the need to go with the grain of local society add a new dimension to understanding the actual operation of Chinese churches.

Furthermore, the grassroots Chinese Christians' experience highlights the importance of the church as a major building block and a viable civic institution in the midst of widespread chaos and unrest. When dynastic collapse and intense warlord conflicts shattered the pre-existing socio-political order, the church stepped in and partnered with local authorities in the realm of disaster management. Many urban and rural Christians emerged socially autonomous and economically independent. Last but not least, both the Nationalists and Communists first experimented with the tactic of mass mobilization against Chinese Christians and formalized a revolutionary strategy of co-opting, infiltrating, and subverting the church during the Anti-Christian Movement (19251926). This laid the foundation for hostile attitudes and norms that greatly impacted church-state conflicts in the Maoist era and even in contemporary China. These features provide key threads - the impacts of regime change, the Christians' encounters with the secular forces of state-building, the church's involvement in transforming local religious and socioeconomic landscapes, and the importance of religious agency — that have shaped the making of Chinese Christianities.

It is worth mentioning that the research conditions in each Chinese archive vary from place to place and from time to time. The Shanghai Municipal Archives is considered by scholars to be the most user-friendly institution because its outstanding staff is headed by professional historians, who try to make archival materials easily accessible to researchers. In Shanghai, Lee discovered several accusation reports against the Seventh-day Adventists and the Roman Catholics during the 1950s. These reports were labelled as "highly confidential" (mimi) but researchers could access them in print and online. The political nature of these reports presents a methodological problem for research. Written in the orthodox Maoist discourse and intended for Communist Party officials in charge of public security and religious affairs, the accusation materials characterized these Christian leaders as "counterrevolutionaries," "reactionary forces," and "class enemies." Communist authorities, however, applied these accusatory terms to both Christians and non-Christians to justify their persecution by all available means, including state violence. The indiscriminate use 
of these terms is just one example of the anti-Christian biases that color the official sources. What are missing in these archives are the subtle relationships that had shaped the encounters between Christians and non-Christians. Nor is there any data on local Christians' feelings of many complex and different subjects in connection with the origins of their communities. Lack of ethnographic perspectives is another methodological problem to be encountered. The only way to overcome this problem is to do fieldwork among Christian communities.

The personal dimension and the unique political conditions in China make the field research and ethnographical work among Christian communities particularly challenging. There are several elements affecting the fieldwork conditions in China. First is the high level of literacy. As a literate society, there are numerous written materials produced by Chinese Christians in every locality: genealogies, account books, land deeds, Sunday school textbooks, religious pamphlets, sermons and diaries. After many years of fieldwork in the New Territories of Hong Kong and the Pearl River delta, David Faure (1998: 14-15) urges anthropologists and historians to pay attention to the value of these written materials in the study of literate cultures in rural China. Faure's suggestion ought to be taken seriously by scholars researching the Chinese church history because despite many decades of political turmoil in twentieth-century China, local Christians often keep their congregational accounts, baptism records, sermons, hymnals, church deeds, foundation stones of old church buildings and Christians' gravestones, all of which are seldom found in the Western missionary and Chinese official archives.

The second element is the size and diversity of China. Although Han Chinese constitute $91 \%$ of the population of 1.4 billion and inhabit a vast landscape, almost 10 million square kilometers of terrain, they speak a variety of dialects at the local level. The other 55 officially recognized ethnic minorities, called shaoshu minzu in Chinese, have their own languages and reside in China's northern, northwestern, western, and southwestern frontiers. In Lee's fieldwork experience, the northeast of Guangdong Province was characterized by great dialectal diversity where the native tongues are the Chaozhou-dialect on the coast and the Hakka-dialect in the interior. The same can be said of Fujian Province and Zhejiang Province's Wenzhou, widely called "China's Jerusalem" due to the high concentration of Protestants in the city (Cao 2010). Without a good knowledge of the dialects, it is hard to conduct long-term field 
research because the pre-1949 generations of inhabitants are not educated in the Mandarin and often perceive Mandarin speakers as suspicious outsiders.

The third element is the political structure of China. The People's Republic of China is a one-party state in which the real authority lies with the Chinese Communist Party. The country is governed by a dual system of tight control, with two imposing bureaucracies coexisting side by side. The interests of the state and the Communist Party are intertwined. The state institutions control the ideological, political, social, economic and religious spheres, and the Communist Party runs the state. Because of China's centralized bureaucracy, researchers who do not have personal connections may need to go through all the political, social and religious hierarchies in preparation for field research. That is to obtain approval from government officials and church leaders at the provincial, municipal and district levels before visiting some Christian villages and neighborhoods. Similar to those nineteenth-century missionaries, any outsiders have to claim some identities and renounce others at different moments of the field research.

During Lee's field study among rural Christians in South China, the most important task was to establish his credibility as a trustworthy researcher. He found himself in a complicated web of social relations with his informants, who were the local government officials in charge of religious affairs, patriotic and unregistered church leaders, and ordinary church worshippers. His relations with them highlighted the comparative advantages and disadvantages of being an outsider and semi-insider, and the cross-cultural communication problems involved. Though being a Hong Kong Chinese of Chaozhou origin, he encountered many identity problems and power relationships that troubled native ethnographers doing fieldwork in their own societies rather than scholars from the West.

Speaking the local dialect, Lee assumed that local people and their ways of life would be easily accessible to him, but he was proven wrong because of the following reasons. First, being a Hong Kong Chinese of Chaozhou descent was not always to his advantage. In China, the stereotypes of Hong Kong Chinese are wealthy merchants and successful professionals like doctors, engineers and accountants. Being neither of those professions put him outside the stereotypes and placed him in an obscure situation. Having learnt about his family background and scholarly interests, the local officials helped him in the fieldwork. Among themselves, they referred to his as "an Overseas Chinese student visiting his parents' homelands." Neither a complement nor a criticism, the statement simply implied that they considered him an outsider.

Secondly, while asking for the official approval and assistance, Lee realized that his Christian background and academic interest in the local church 
history would cause problems. Deliberately positioning himself as a patriotic son in search of Chaozhou cultural roots, he utilized the Marxist discourse to frame his research as the study of Western imperialism and Chinese Christian patriotism to avoid suspicion. He also avoided any criticism of church-state relations after 1949. These tactics created an ideological common ground with the officials. While most officials connected him with their colleagues in rural townships, they wondered why he wasted time among "ignorant peasants" rather than working comfortably in the air-conditioned archives and libraries. Underlying this question is the officials' perception of peasants as superstitious, backward and inert. According to Myron L. Cohen (1993), such attitude reveals more about the official prejudices towards peasant communities than the living conditions in the Chinese countryside. Lee replied by citing Chairman Mao Zedong's famous remark, "Unless one investigates a problem, one has no right to speak of it" (Mao 1930). Mao, in 1930, urged his comrades to conduct in-depth investigation before organizing any class struggle in rural society. Lee explained to the officials that without seeing the physical conditions of Christian settlements, he would not be in a position to comment on the history of Christianity in South China. Clearly, Chairman Mao's insight is still relevant to the study of China today.

It was a good start to secure the officials' approval but their help was not enough. The next step was to obtain the assistance of the patriotic church leaders. The situation became more complicated when Lee met different generations of local Christians. Many local Catholic and Protestant patriotic church leaders criticized the late-nineteenth-century Western missionaries as cultural imperialists. However, seeking to cultivate good relations with Overseas Chinese Christians, they downplayed any church-state tensions after 1949. Besides the patriotic church leaders, Lee met a number of elderly ministers who commanded much respect among the ordinary believers. While they joined the religious patriotic institutions, they were critical of the Communist government's intervention into native church affairs. Having told them about his kinship connection with the Baptist communities, they immediately accepted Lee as a friend and took him to rural congregations.

In the countryside, the idea of a person being not part of a community or being alone was totally inconceivable. Lee was in a unique situation of being simultaneously a Hong Kong-born, British-educated and US-based researcher, a Chaozhou-speaking investigator by virtue of his family upbringing, and a Protestant (Lutheran) by his church affiliation. He was an insider because of the kinship connection and religious faith; he was a semi-insider due to his distant kinship connection with the Catholics there; and to the worshippers of popular Buddhist and Daoist deities, he was a complete outsider. These 
multiple identities were imposed upon him by both historical circumstances and the informants' perceptions. When he was aware of these identities, he employed them as best as he could in order to gain trust from different groups of informants.

During the fieldwork, Lee accepted church tours organized by the rural congregations. The sequence of each tour-beginning from those households directly related to his tour guides and ending at the church buildingsprojected the guide's dual kinship and Christian identities, be they Catholic or Protestant. It was extremely difficult to find people available to give first-hand accounts of the events in the late nineteenth century. In view of this problem, he visited old church buildings, Christian households, lineage halls, temples, village walls, watch towers and schools. He took pictures of these architectural remains, enquired about the backgrounds surrounding these constructions, and investigated the material culture of local Christian movements. Through these visits, he sketched those villages where the Christian congregations were located, and mapped the settlement areas of different lineage factions and religious groups. On various visits, he brought the local church membership records that he photocopied from the Chinese state archives. He asked some elderly people to identify the lineage factions to which these Christians belonged, and the locations of their former and present households. Whenever possible, he interviewed the descendants of the local church founders who reconstructed what their religious communities had been like in the late nineteenth and early twentieth centuries, and what had changed after 1949. On other occasions, Lee's Protestant identity proved to be an obstacle, especially when he met Buddhist and Daoist monks. Their suspicion had much to do with the longstanding hostility between Christians and non-Christians at the village level. Even nowadays, many Christian leaders assert that Christianity is superior to Buddhism, Daoism and other folk religions, and that temple worshippers are "profane" (shisu) and doomed to eternal death on the Day of Judgment. Underlying this remark is a continuity of the late-nineteenthcentury Western missionary worldview that divided the world in good and evil, and believed in a religious battle between a Christian God and evil spirits. This sense of Christian superiority is only a cultural concept, and Lee decided not to use the language of superiority in conversation with temple managers. While visiting temples, he respected popular religious rituals and tried to avoid being seen by Catholics and Protestants.

When he revisited these Christian settlements in the early 2o1os as part of a longitudinal research into the changing Chinese religious landscape, these rural congregations were greatly impacted by the inflows and outflows of migration. Younger Christian families moved to metropolitan cities to seek 
better education and career opportunities, and the congregations were made up of elderly worshippers. The wealthy villages attracted migrant laborers from inland provinces like Anhui and Sichuan. Some migrants were Christian. Though they did not always speak the southern Chinese dialects, they attended church services. The rural congregations sought new resources and hired educated pastors to minister to the newcomers. Meanwhile, the elderly villagers provided contacts of their relatives in the cities, and this allowed Lee to carry out multi-site research and examine the cross-regional networks of these churches.

These challenges notwithstanding, taking field notes and keeping a diary enables the researcher to stabilize one's position in times of uncertainties. Throughout his stay at the Christian communities, he employed the anthropological approach of participant observation. By attending church events, he realized that Christianity had become an important part of the cultural identity and social practices. Welcoming him as a guest, the local Christians discussed the history of their family connection with the late-nineteenth-century Baptist and Presbyterian missions, their memory of religious persecution during the Maoist period, and their role of reviving Christian activities in the recent decades. They challenged the Chinese Communist version of the church history by arguing that nineteenth-century Protestant missionaries had empowered their ancestors. Their personal insights draw attention to the complex meanings of history and memory as well as to the use of oral history and remembrance as a source for historical research among these believers in South China (Jing 1996; Wang 2020; Weigelin-Schwiedrzik 2009). Clearly, it was impossible for them to safeguard their churches against state-imposed Three-Self Patriotic Movement after 1949. Despite their powerlessness, they would seize any opportunity to express their outrage against the Maoist state. The opportunity eventually came in the 198 os when they were permitted to rebuild the churches across Chaozhou. The significance of the church reconstruction efforts lies in the fact that local congregants took advantage of the changing political climate in Beijing to re-establish their Christian strongholds during the Reform era. Upon the end of the field study, researchers can make use of social media technologies to ask informants further information. For example, after finishing her fieldwork among Seventh-day Adventists in Wenzhou, Christie Chui-Shan Chow turned to WeChat and QQ, the Chinese equivalents of Facebook and Twitter, to obtain ethnographic data, policy documents and photographic evidence about the recent cross demolition campaigns. It was through these Chinese social media platforms that Chow interviewed Christian informants and traced the origins, development and impacts of cross removal incidents in rural Wenzhou (Chow 2016). 
The interplay between the global and local forces in Christianities in China has taught us three important lessons. The first lesson concerns the exploration of multiple source materials. Church historians should pay attention to a wide range of primary sources such as foreign missionary archives, native church records deposited in state and municipal archives (as shown in China), private papers of prominent church leaders and Christian families, oral history and ethnographic evidence about the material culture of Christianity in unique local settings. At least in China, combining archival research with multi-site fieldwork and social media technologies allows scholars to conduct a longitudinal research into the transformation of Christian religious landscape in any locality.

The second lesson is a methodological one. Scholars should address the question of how the changing religious and political landscape has shaped both the accessibility of archival sources and the way these sources are conceived within the larger narratives of official historiography. In an authoritarian state like China, it is always a challenge for researchers to access church archival materials in state-controlled national and municipal archives (Reny 2016). After overcoming the institutional barriers and accessing the primary sources, scholars have to be critical of the ideological settings in which these materials were produced, catalogued and preserved by government officials, and the anti-religious biases that were mobilized to interpret the faith experience of individual believers and church communities. As Chloë F. Starr (2017: 234) asserts, because Chinese church-state relations are as much influenced by political forces as by theological discussions, the analytical discourse should take into account the corrosive effects of state fiats, official slogans, and secular ideologies on the churches. Perhaps collaborations with native church historians will enable international researchers to bypass state censorship, develop genuine academic partnerships, and access a great deal of historical, ethnographic and theological data produced by local Christians. These collaborations will also advance global knowledge exchange and raise awareness about transnational church networks.

The third lesson is a thematic one. Global theologies and denominations have been as influential as local evangelistic agents and faith practices in shaping the development of wider Christian landscape. The global Christian inputs were embedded into the Chinese ecclesial and theological orientations. In fact, abstract discussion about global-local church ties mattered little to Chinese Christians when it came to defending their faith and constructing a meaningful worldview in times of chaos and instability. Their Christian faith provided them with strong spiritual capital to sustain themselves. By emphasizing the 
centrality of the Bible in shaping their identity, they went through a gradual process of coming to terms with the meaning of being a faithful Christian in times of persecution. This reflected their spiritual transformation through the support they received from their families and congregations towards a more personal relationship with the Christian God, and kept them from abandoning their faith.

In a nutshell, the generalizations of 'World Christianity' and 'Chinese Christianity' only make sense in analytical terms because Christianity always adapts to the cultural conditions of any locality. The indigenization of Christianity has never been unidirectional, and this requires a closer look at the concrete circumstances in which religious interactions take place. This chapter calls on scholars to conduct archival and library research, fieldwork, and social media communication as new viable approaches to studying the history of Christianities worldwide. In an authoritarian country like China where the state controls the researcher's access to the archives, using such mixed methods should yield important findings on the complexity of Chinese Christians' experience and their everyday interactions with government officials of all levels. In particular, fieldwork affords an intimate encounter between the researcher and informants in contextual settings such as church meetings, worships and communal praying, allowing the researcher to critique misconceptions and biases displayed in written church archives and official documents, and to synthesize the data, both written and oral, from the believers' perspectives. In his recent study of the proliferation of Christian evangelistic movements, Brian Stanley remarks, "The battle for the integrity of the gospel in the opening years of the twenty-first century is being fought not primarily in the lecture rooms of North American seminaries but in the shanty towns, urban slams and villages of Africa, Asia, and Latin America" (Stanley 2013: 247). Since the dynamics of Christianity worldwide are evolving in ordinary believers' real life situations, the researcher has to go native, being 'on the ground', observing the congregations upfront and participating in their life. Only by testing traditional archival sources against fieldwork can the researcher humanize the wide varieties of Christian movements and study their historical experiences in greater depth.

\section{Bibliography}

Austin, Alvyn (2007). China's Millions. The China Inland Mission and Late Qing Society, 1832-1905. Grand Rapids, MI: William Eerdmans.

Bays, Daniel H. (1996). 'The Growth of Independent Christianity in China, 1900-1937' In Daniel H. Bays, ed., Christianity in China. From the Eighteenth Century to the Present. Stanford, CA: Stanford University Press: $307-316$. 
Bays, Daniel H. (2003). 'Chinese Protestant Christianity Today.' The China Quarterly 174: 488-504.

Bays, Daniel H. (2013). 'Reflection of Protestantism and Modern China. Problems of Periodization.' The Chinese Historical Review 20,1: $5^{-15}$.

Bays, Daniel H., and Ellen Widmer, eds. (2009). China's Christian Colleges. Cross-Cultural Connections, 1900-1950. Stanford, CA: Stanford University Press.

Cao, Nanlai (2010). Constructing China's Jerusalem. Christians, Power, and Place in Contemporary Wenzhou. Stanford, CA: Stanford University Press.

Chan, Kim-Kwong (2019). Understanding World Christianity. China. Minneapolis, MN: Fortress Press.

Chow, Christie Chui-Shan (2015). 'Vision and Division. Christian Schisms in Contemporary China.' Ph.D. dissertation, Princeton Theological Seminary.

Chow, Christie Chui-Shan (2016). 'Demolition and Defiance. The Stone Ground Church Dispute (2012) in East China.' The Journal of World Christianity 6,2: 250-276.

Chow, Christie Chui-Shan, and Joseph Tse-Hei Lee (2016). 'Covert and Overt Activism. Christianity in 1950s China.' Frontiers of History in China 11,4: 579-599.

Chow, Christie Chui-Shan (forthcoming). Schism. How Adventism is Reshaping Post-Denominational China. Notre Dame, IN: University of Notre Dame Press.

Clark, Anthony E. (2011). China's Saints. Catholic Martyrdom during the Qing (1644-1911). Bethlehem, PA: Lehigh University Press.

Cohen, Myron L. (1993). 'Cultural and Political Inventions in Modern China. The Case of the Chinese "Peasant".' In Tu Wei-Ming, ed., China in Transformation. Cambridge: Harvard University Press: 151-170.

Constable, Nicole (1994). Christian Souls and Chinese Spirits. A Hakka Community in Hong Kong. Berkeley, CA: University of California Press.

Dubois, Thomas David, and Jan Kiely, eds. (2020). Fieldwork in Modern Chinese History. A Research Guide. New York: Routledge.

Dunch, Ryan (2014). 'Review of The Missionary's Curse and Other Tales from a Chinese Catholic Village, by Henrietta Harrison.' Harvard Journal of Asiatic Studies 74,2: 336-337.

Faure, David (1998). 'The Historical Uses of Ethnography.' Hong Kong Anthropology Bulletin 1: 14-15.

Harrison, Henrietta (2013). The Missionary's Curse And Other Tales from a Chinese Catholic Village. Stanford, CA: Stanford University Press.

Harvey, Thomas A. (2002). Acquainted with Grief. Wang Mingdao's Stand for the Persecuted Church in China. Grand Rapids, MI: Brazos Press.

Inouye, Melissa Wei-Tsing (2019). China and the True Jesus. Charisma and Organization in a Chinese Christian Church. Oxford: Oxford University Press.

Jenkins, Philip (2002). The Next Christendom. The Coming of Global Christianity. Oxford: Oxford University Press. 
Jing, Jun (1996). The Temple of Memories. History, Power, and Morality in a Chinese Village. Stanford, CA: Stanford University Press.

Kraus, Charles (2016). Researching the History of the People's Republic of China. Cold War International History Project Working Paper No. 79. Retrieved on February 16, 2018 from https://www.wilsoncenter.org/publication/researching-the -history-the-peoples-republic-china.

Lee, Joseph Tse-Hei (2005). 'Watchman Nee and the Little Flock Movement in Maoist China.' Church History 74,1: 68-96.

Lee, Joseph Tse-Hei (2007). 'Christianity in Contemporary China. An Update.' Journal of Church and State 49,2: 277-304.

Lee, Joseph Tse-Hei (2014). 'Faith and Charity. The Christian Disaster Management in South China.' Review of Culture 45: 127-138.

Lee, Joseph Tse-Hei (2017). 'Faith and Defiance. Christian Prisoners in Maoist China.' Review of Religion and Chinese Society 4,2: 167-192.

Lee, Joseph Tse-Hei (2018). 'Christianizing Maritime Chaozhou-Shantou.' In Joseph Tse-Hei Lee, ed., Christianizing South China. Mission, Development, and Identity in Modern Chaoshan. New York: Palgrave Macmillan: 1-14.

Lee, Joseph Tse-Hei and Lars Peter Laamann (2019). 'Christianity and Community Governance in Modern China.' In Lars Peter Laamann and Joseph Tse-Hei Lee, eds. The Church as Save Haven. Christian Governance in China. Leiden: Brill: 1-16.

Lian, Xi (2010). Redeemed by Fire. The Rise of Popular Christianity in Modern China. New Haven, CT: Yale University Press.

Ling, Oi-Ki (1999). The Changing Role of the British Protestant Missionaries in China, 1945-1952. Madison, NJ: Fairleigh Dickinson University Press.

Lutz, Jessie G. (2008). Opening China. Karl F.A. Gutzlaff and Sino-Western Relations, 1927-1852. Grand Rapids, MI: Wm. B. Eerdmans.

Madsen, Richard (2003). 'Catholic Revival during the Reform Era.' The China Quarterly 174: 468-487.

Mao, Zedong (1930). 'Oppose Book Worship.' Retrieved on February 16, 2018 from http://www.maoism.org/msw/vol6/mswv6_11.htm.

Peel, John D.Y. (1996). 'Problems and Opportunities in an Anthropologist's Use of a Missionary Archive.' In Robert A. Bickers and Rosemary Seton, eds. Missionary Encounters. Sources and Issues. Richmond, Surrey: Curzon Press: 70-94.

Reny, Marie-Eve (2016). 'Authoritarianism as a Research Constraint. Political Scientists in China.' Social Sciences Quarterly 97,4: 909-922.

Roberts, Dana (2005). Secrets of Watchman Nee. Gainesville, FL: Bridge-Logos.

Stanley, Brian (2013). The Global Diffusion of Evangelicalism. The Age of Billy Graham and John Stott. Downers Grove, IL: IVP Academic.

Starr, Chloë F. (2017). 'Maintaining Faith in the Chinese Church.' In Joel Cabrita, David Maxwell and Emma Wild-Wood, eds. Relocating World Christianity. Interdisciplinary Studies in Local and Universal Expressions of Christianity. Leiden: Brill: 213-237. 
Sweeten, Alan Richard (2001). Christianity in Rural China. Conflict and Accommodation in Jiangxi. Ann Arbor, MI: Center for Chinese Studies, University of Michigan.

Tiedemann, Rolf G. (2012). 'Comity Agreements and Sheep Stealers. The Elusive Search for Christian Unity among Protestants in China.' International Bulletin of Missionary Research 35,1: 3-8.

Tiedemann, Rolf G., ed. (2010). Handbook of Christianity in China. Volume Two: 180oPresent. Leiden: Brill.

Wagner, Vivian (1998). 'The Management of Memory in the PRC. How to Keep Pandora's Box Tightly Closed.' Paper presented at the vir European Association of Chinese Studies Conference in Edinburgh, September 10-13.

Wagner, Vivian (2002). 'Class Struggle and Commerce. Utilizing the Archival Heritage of the PRC.' Paper presented at the XIV European Association of Chinese Studies Conference in Moscow, August 26-28.

Wang, Peter Chen-Main, ed. (2007). Contextualization of Christianity in China. Evaluation in Modern Perspective. Sankt Augustin: Institut Monumenta Serica.

Wang, Xiaoxuan (2020). Maoism and Grassroots Religion. The Communist Revolution and the Reinvention of Religious Life in China. Oxford: Oxford University Press.

Weigelin-Schwiedrzik, Suzanne (2006). 'In Search for a Master Narrative.' The China Quarterly 188: 1086-1087.

Wickeri, Philip L. (2007). Reconstructing Christianity in China. K.H. Ting and the Chinese Church. Maryknoll, NY: Orbis Books.

Wickeri, Philip L., ed. (2015). Christian Encounters with Chinese Culture. Essays on Anglican and Episcopal History in China. Hong Kong: Hong Kong University Press.

Woodbridge, David (2019). Missionary Primitivism and Chinese Modernity. The Brethren in Twentieth Century China. Leiden: Brill.

Wu, Silas (2002). Dora Yu. Harbinger of Christian Church Revival in 2oth-Century China. Boston, MA: Pishon River Publications.

$\mathrm{Wu}$, Xiaoxin, ed. (2005). Encounters and Dialogues. Changing Perspectives on ChineseWestern Exchanges from the Sixteenth to Eighteenth Centuries. Sankt Augustin: Institut Monumenta Serica.

Wuthnow, Robert (2010). Boundless Faith. The Global Outreach of American Churches. Berkeley, CA: University of California Press.

Yang, Huilin (2014). China Christianity and the Question of Culture. Waco, TX: Baylor University Press.

Ye, Wa, and Joseph W. Esherick (1996). Chinese Archives. An Introductory Guide. Berkeley, CA: Center for Chinese Studies, Institute of East Asian Studies, University of California. 